Vol. 07, No. 01; 2022

ISSN: $2456-8643$

\title{
APPLICATION AGRICULTURAL WASTE COMPOST AND INORGANIC FERTILIZER TO INCREASE ORGANIC-C, PLANT NITROGEN, CHLOROPHYLL, GROWTH AND CORN YIELD
}

\author{
Mieke Rochimi Setiawati, Diyah Sri Utami, Reginawanti Hindersah,Diyan Herdiyantoro, Pujawati \\ Suryatmana, and Nadia Nuraniya Kamaluddin \\ Soil Science Department, Agriculture Faculty of Universitas Padjadjaran. ,Jl. Raya Bandung Sumedang Km 21 \\ Jatinangor Kab. Sumedang 45363, Indonesia \\ https://doi.org/10.35410/IJAEB.2022.5706
}

\begin{abstract}
Utilization of agricultural waste as organic fertilizer has the potential to increase soil fertility and increase nutrient availability. The application of inorganic fertilizer is intended to balanced the availability of nutrients and increase the productivity of corn plants. The purpose of this study was to determine the effect and interaction between various organic fertilizers with inorganic fertilizers to increase C-organic, plant nitrogen, chlorophyll, growth and yield of corn (Zea mays) Bisi-2 variety on Inceptisols soil. The research was conducted from July 2020 to January 2021 in the experimental screen house at Ciparanje, Agriculture Faculty, Universitas Padjadjaran, Jatinangor, West Java, 724 meters above the sea level. This research design used a randomized block design factorial with 16 treatments and three replicates. The first factor was the type of organic fertilizer of four levels: without organic fertilizer (control), 10ton ha-1 of rice straw, sugarcane bagasse, and oil palm empty fruit bunches (OPEFB) compost. The second factor was the dosage of inorganic fertilizers of four levels: without inorganic fertilizer (control), 50\%, 75\% and $100 \%$ of dose recommendation inorganic fertilizer. The results showed that no interaction between organic fertilizers and inorganic fertilizers against all the parameters. The effect of the OPEFB 10 ton ha-1 treatment was the best treatment on the cob weight without husks 113.86 $\mathrm{g} / \mathrm{plant}$. The application of $100 \%$ inorganic fertilizer was not difference with $50 \%$ inonganic fertilizer that produced cob weight without husks $114.63 \mathrm{~g} / \mathrm{plant}$.
\end{abstract}

Keywords: Rice Straw, Sugarcane Bagasse, Oil Palm Empty Fruit Bunches, Compost, Corn.

\section{INTRODUCTION}

Corn is a strategic commodity in Indonesia, the highest projected increase is around $3.6 \%$ per year [1]. In 2019 the national corn crop productivity was 10 ton ha $^{-1}$ [2]. Efforts to increase the productivity of corn plants can be done by fertilizing. Nutrient nitrogen is needed by corn plants starting from the vegetative phase to the generative phase. Continuous use of inorganic fertilizers alone causes soil organic matter degradation, soil acidity and environmental pollution [3]. The use of inorganic fertilizers integrated with organic fertilizers is a sustainable approach [4].

Rice straw, one of the largest agricultural wastes in Indonesia, has the potential to be used as organic fertilizer by composting. Rice straw contains nutrients, including: $\mathrm{N} 0.8 \%, \mathrm{P} 0.12 \%, \mathrm{~K}$ $(1.7 \%)$ and $\mathrm{S}(0.10 \%)$ [5]. There was an interaction between treatments of 10 ton $\mathrm{ha}^{-1}$ rice straw compost with $130 \mathrm{~kg} \mathrm{ha}^{-1}$ urea, $200 \mathrm{~kg} \mathrm{ha}^{-1}$ Chrismast Island Rock Phosphate (CIRP), $67 \mathrm{~kg} \mathrm{ha}^{-1}$ Muriate of Potash (MOP) can increase nitrogen in the soil and plant nitrogen uptake [6]. Rice 
straw compost wich is applied to soil can increase C-organic, $\mathrm{N}$ uptake and $\mathrm{P}$ uptake of corn plants [7].

Bagasse is an agricultural waste that is widely available in Indonesia which can be used as organic fertilizer. Sugarcane bagasse is a cellulosic agro-industrial byproduct released after crushing and extracting juice from the canes. It is a dry, pulpy residue and is fibrous in nature [8]. The byproducts of sugar plant during sugar production are pressmud cake (3.4\%) and sugarcane bagasse (25-30\%) [9]. Application of 10 tons ha ${ }^{-1}$ of bagasse compost is the best dose that gives to a mung beans yield was 2.07 tons ha ${ }^{-1}[10]$.

Oil palm empty fruit bunches (OPEFB) have the potential to be used as organic fertilizer. OPEFB contains 70-80\% carbon sources, namely cellulose, hemicellulose and lignin 27.6-32.5\% [11]. Based on the research of [12] the application of OPEFB compost combined with NPKMg has an effect on increase $\mathrm{C}$-organic, $\mathrm{N}$-total, $\mathrm{C} / \mathrm{N}$ ratio. Based on the research of [13] using a formulation of 10 tons ha-1 of OPEFB compost with $75 \mathrm{~kg} \mathrm{ha}^{-1}$ of NPK fertilizer, the weight of the cob without husk weight was 37.8 tons ha-1.

[14] reported the results of his research that combined organic and inorganic fertilization can increase $\mathrm{N}$ efficiency, increase corn seed production and can accumulate $\mathrm{C}$ in the soil. Based on this background, the objectives of this study were to determine the interaction between organic fertilizers and inorganic fertilizers, and to find out the best combination of types and doses of compost and inorganic fertilizers in increasing organic C, plant nitrogen, chlorophyll, growth and yield of corn on Inceptisols.

\section{MATERIALS AND METHODS}

The research was carried out from July 2020 to January 2021 at the screen house Faculty of Agriculture, Universitas Padjadjaran, Jatinangor District, Sumedang Regency, West Java, Indonesia.

The materials used in the study were: Bisi-2 variety corn seeds, Inceptisols soil planting medium, polybags with a size of $20 \times 40 \mathrm{~cm}$ (10 kg soil volume), agricultural waste compost in the form of rice straw compost (organic-C: $20.54 \%, \mathrm{~N}: 0.80 \%, \mathrm{C} / \mathrm{N}: 25.67$ ), OPEFB compost (organic-C: $30.58 \%, \mathrm{~N}: 1.06 \%, \mathrm{C} / \mathrm{N}: 28.85$ ), and bagasse (organic-C: $24.46 \%, \mathrm{~N}: 0.64 \%, \mathrm{C} / \mathrm{N}$ : 38.22). Microbial decomposer which was use as decomposer of compost material activator derived from termite nests ( $10 \%$ by volume of compost material). Fertilizer Urea ( $46 \% \mathrm{~N})$, SP$36\left(36 \% \mathrm{P}_{2} \mathrm{O}_{5}\right)$ and $\mathrm{KCl}\left(60 \% \mathrm{~K}_{2} \mathrm{O}\right)$, insecticide Callicron $500 \mathrm{EC}$ and fungicide (Dithane M-45) with a concentration of $3 \mathrm{~g} \mathrm{liter}^{-1}$.

This research was conducted using a $4 \times 4$ factorial randomized block design. The research consisted of 16 combination treatments of organic and inorganic fertilizers. Each treatment was repeated 3 times. The treatment consisted of two factors, the first factor was the type of organic fertilizer consisting of four levels, namely without giving organic fertilizer (control), rice straw compost, OPEFB compost and bagasse compost of 10 tons ha ${ }^{-1}$ each dose. The second factor was the dose of inorganic fertilizer at four levels, namely without inorganic fertilizer (control), 50\% of the recommended inorganic fertilizer dose $\left(150 \mathrm{~kg} \mathrm{ha}^{-1}\right.$ Urea, $66 \mathrm{~kg} \mathrm{ha}^{-1} \mathrm{SP}-36,75 \mathrm{~kg} \mathrm{ha}^{-1}$ $\mathrm{KCl}), 75 \%$ recommended dose of inorganic fertilizer $\left(225 \mathrm{~kg} \mathrm{ha}^{-1}\right.$ Urea, $99 \mathrm{~kg} \mathrm{ha}^{-1} \mathrm{SP}-36,112.5$ $\left.\mathrm{kg} \mathrm{ha}^{-1} \mathrm{KCl}\right)$ and $100 \%$ recommended inorganic fertilizer dose $\left(300 \mathrm{~kg} \mathrm{ha}^{-1}\right.$ Urea, $132 \mathrm{~kg} \mathrm{ha}^{-1} \mathrm{SP}-$ 36 and $\left.150 \mathrm{~kg} \mathrm{ha}^{-1} \mathrm{KCl}\right)$. 
Inceptisols as planting medium were carried out using soil composite samples at $0-20 \mathrm{~cm}$ a depth from the soil surface. Soil planting media of $10 \mathrm{~kg}$ per polybag was treated with organic fertilizer of rice straw, OPEFB and bagasse compost 10 tons ha $^{-1}$ each dose which was applied 1 week before planting and the dose of inorganic fertilizer was according to treatment. Urea fertilizer was given in three application, first at 7 days after planting (DAP) as $30 \%$ of the total dose, second at 30 DAP $30 \%$ of the total dose and in third when it was 45 DAP $40 \%$ of the total dose. $\mathrm{KCl}$ fertilization was carried out twice, $50 \%$ of the total dose given at 7 DAP and 30 DAP. All SP-36 fertilizer was given according to the treatment dose at 7 DAP.

The parameters observed in this study were: (a) Vegetative growth by measuring plant height at 2, 4, 6, 8 weeks after planting (WAP) and chlorophyll in leaf plants at 8 WAP, (b) organic-C using the Walkey and Black method at 8 WAP, (c) Plant nitrogen using the Kjeldahl method at 8 WAP, (d) cobs weight with and without husk were observed at generative phase (14 WAP).

Observational data were evaluated with the $\mathrm{F}$ test to determine the difference in responses to plant growth and yield from each treatment. The data obtained were analyzed using Microsoft Office Excel 2019 software and analyzed for variance (ANOVA) using SPSS version 16.0. If there is a significant effect, then the test is continued with Duncan's multiple distance test (DMRT) at a 5\% significance level.

\section{RESULTS AND DISCUSSION}

\section{Soil Analysis Before Experiment}

Based on the results of soil analysis before the experiment, the physical and chemical properties of the Inceptisols soil used in this study is in Table 1. Inceptisols in this study had a neutral soil reaction (6.71), low CEC (14.76 $\mathrm{cmol} \mathrm{kg}^{-1}$ ), low C-Organic (1.67\%), low total $\mathrm{N}$ $(0.18 \%)$. The content of exchangeable cations (CEC) was low. The initial soil analysis data of Inceptisols has a high clay content compared to sand. The chemical and physical properties indicates that soils containing low fertility but have high in base saturation. Soils with high percent base saturation have a higher $\mathrm{pH}$, therefore, they are more buffered against acid cations from plant roots and soil processes that acidify the soil (nitrification, acid rain, etc.).

Table 1. Characteristics of Inceptisols at the beginning of the experiment

\begin{tabular}{|c|c|c|c|c|c|}
\hline No & Parameters & Method & Unit & Value & Criteria \\
\hline 1 & $\mathrm{pH}: \mathrm{H}_{2} \mathrm{O}$ & $\mathrm{H}_{2} \mathrm{O} 1: 1$ & - & 6.71 & Neutral \\
\hline 2 & C-Organic & $\begin{array}{l}\text { Walkey } \\
\text { Black }\end{array}$ & and $\%$ & 1.67 & Low \\
\hline 3 & N Total & Kjeldahl & $\%$ & 0.18 & Low \\
\hline 4 & $\mathrm{C} / \mathrm{N}$ & - & - & 9 & Low \\
\hline 5 & CEC & NH4OAc & $7.0 \mathrm{cmol} . \mathrm{kg}^{-1}$ & 14.76 & Low \\
\hline 6 & Base saturation & $\mathrm{KCl} 1 \mathrm{~N}$ & thod & 65.69 & High \\
\hline \multirow[t]{2}{*}{7} & Texture & Pipette M & & & Clay \\
\hline & Sand & & $\%$ & 4 & \\
\hline
\end{tabular}




\begin{tabular}{|lll|}
\hline Dust & $\%$ & 36 \\
Clay & $\%$ & 60 \\
\hline
\end{tabular}

\section{Soil Organic Carbon}

Organic fertilizers have N, P, and $\mathrm{K}$ macro elements as well as complete microelements but in small amounts. According to [15] organic fertilizer can increase soil fertility and the use of nutrients efficiency. Based on the results of statistical analysis showed that there was no interaction between organic fertilizers and inorganic fertilizers. The treatment of organic fertilizers and inorganic fertilizers independently had no significant effect on organic-C soil (Table 2).

Table 2. Effect of organic and inorganic fertilizer on soil organic-C content

\begin{tabular}{|cl|}
\hline Treatments & Organic-C (\%) \\
\hline Organic Fertilizer & \\
$\mathrm{o}_{0}=$ Without compost application & 1.77 \\
$\mathrm{o}_{1}=$ rice straw compost & 1.74 \\
$\mathrm{O}_{2}=$ bagasse compost & 1.82 \\
$\mathrm{o}_{3}=$ OPEFB compost & 1.88 \\
Inorganic Fertilizer & \\
$\mathrm{a}_{0}=$ Without Inorganic $\quad$ Fertilizer & 1.86 \\
application & \\
$\mathrm{a}_{1}=50 \%$ recomendation dose & 1.72 \\
$\mathrm{a}_{2}=75 \%$ recomendation dose & 1.78 \\
$\mathrm{a}_{3}=100 \%$ recomendation dose & 1.85 \\
\hline
\end{tabular}

The initial organic-C content showed that the three types of organic fertilizers have differed from 20.54 to $30.58 \%$. The organic-C content of organic fertilizer applied to the soil will decrease according to the rate of weathering which is influenced by the content of $\mathrm{N}, \mathrm{P}$, and $\mathrm{K}$ in the soil through fertilization. According to [16] degradation of organic matter can take place quickly if the ratio of the levels of organic-C:N:P:K in the decomposed material is equal to 30:1:0.1:0.5. Organic-C in the treatment of compost various types and inorganic fertilizers with various doses produced the same value compared to the treatment without compost or inorganic fertilizers. This is because the decomposition of organic-C occurs in a biophysico-chemical manner, involving the biological activity of organisms in the soil with sufficient $\mathrm{N}, \mathrm{P}, \mathrm{K}$ content from the inorganic fertilizer provided.

Application of organic fertilizer increased organic- $\mathrm{C}$ in the soil compared to organic- $\mathrm{C}$ soil before application. Before the experiment, the organic-C content of the soil was $1.67 \%$. After the application of organic fertilizer types, the organic-C content the soil slighty increase became $1.74 \%, 1.82 \%$, and $1.88 \%$. Based on research [17] organic fertilizers have a role in improving soil physical, chemical and biological properties.

\section{Nitrogen and Chlorophyll Content of Corn Plant}


Nitrogen is absorbed by corn plants in several forms, including nitrate $\left(\mathrm{NO}_{3}{ }^{-}\right)$and ammonium $\left(\mathrm{NH}_{4}{ }^{+}\right)$. The uptake of nitrogen is influenced by the amount of soil nutrient availability. Based on analysis of variance, it showed that there was no interaction between organic fertilizer and inorganic fertilizer on corn plant nitrogen content (Table 3). This is due to nitrogen is one of the most susceptible macronutrients to environmental loss, such as ammonia volatilization, nitrous oxide emissions, and nitrate leaching [18].

The independent effect of organic fertilizer of OPEFB showed a significant difference to nitrogen in corn plants. Based on the analysis before the experiment, OPEFB compost had higher nitrogen than two other organic fertilizers. Application of organic fertilizers can increase nutrient uptake, especially nitrogen by decreasing mineral leaching [19].

Table 3. Effect of organic and inorganic fertilizer on plant nitrogen and chlorophyll content

\begin{tabular}{|c|c|c|c|}
\hline Treatments & & $\begin{array}{l}\text { Nitrogen Content } \\
(\%)\end{array}$ & $\begin{array}{l}\text { Chlorophyll } \\
\text { (CCI) }\end{array}$ \\
\hline \multicolumn{4}{|l|}{ Organic Fertilizer } \\
\hline $\mathrm{O}_{0}=$ without compost application & & $1.75 \mathrm{a}$ & $22.41 \mathrm{a}$ \\
\hline $\mathrm{o}_{1}=$ rice straw compost & & $1.76 \mathrm{a}$ & $23.10 \mathrm{a}$ \\
\hline $\mathrm{O}_{2}=$ bagasse compost & & $1.77 \mathrm{a}$ & $21.74 \mathrm{a}$ \\
\hline $\mathrm{O}_{3}=\mathrm{OPEFB}$ compost & & $2.20 \mathrm{~b}$ & $23.08 \mathrm{a}$ \\
\hline \multicolumn{4}{|l|}{ Inorganic Fertilizer } \\
\hline $\begin{array}{l}\mathrm{a}_{0}=\text { Without Inorganic } \\
\text { application }\end{array}$ & Fertilizer & $1.51 \mathrm{a}$ & $24.64 \mathrm{~b}$ \\
\hline $\mathrm{a}_{1}=50 \%$ recomendation dose & & $2.15 \mathrm{~b}$ & $24.88 \mathrm{~b}$ \\
\hline $\mathrm{a}_{2}=75 \%$ recomendation dose & & $1.83 \mathrm{ab}$ & $17.97 \mathrm{a}$ \\
\hline$a_{3}=100 \%$ recomendation dose & & $1.98 \mathrm{~b}$ & $22.84 \mathrm{ab}$ \\
\hline
\end{tabular}

Note: Numbers followed by the same letter are not significantly different at the 5\% Duncan test level.

Chlorophyll has a positive correlation with photosynthesis which affects plant growth and yield [20]. According to [21] nitrogen is a constituent of enzymes and chlorophyll molecules that play a role in the photosynthesis process. The results of the analysis showed that there was no interaction between the treatment of organic fertilizers and inorganic fertilizers on leaf chlorophyll. The independent effect of organic fertilizer was not significantly different between treatments on leaf chlorophyll. It is suspected that the low activity of soil microorganisms causes low nitrogen mineralization. The independent effect of inorganic fertilizer treatment had a significant effect on the nitrogen of corn plants. Treatment of application of inorganic fertilizer $50 \%$ recommended dose showed a significant difference with no inorganic fertilizer (control). The application of 50\% inorganic fertilizer at the recommended dose showed nitrogen content $2.15 \%$, higher than the control but not different from other inorganic fertilizer doses. Inorganic fertilizers are easily to be available so it can be absorbed directly by plants.

The use of $50 \%$ inorganic fertilizer provides sufficient and more optimal nutrients for corn plants. Several factors such as the application of organic fertilizers can make inorganic fertilizers efficient by $25-50 \%$, because organic fertilizers can mineralize about $5-10 \%$ of 
nitrogen so that it becomes available to plants through the process of improving the physical, chemical and biological properties of the soil. [20] stated that sufficient nitrogen content can increase the chlorophyll content of corn plants.

\section{Corn Plant Height}

Corn plant height showed increased in each observation. Observations were made at the age of plants 2 upto 8 weeks after planting (WAP). At the age of $8 \mathrm{WAP}$, this period reached the maximum plant height. Organic fertilizer and inorganic fertilizer treatments showed no significant difference between treatments on plant height at plant age of 2, 4 and 6 WAP, but showed a difference at plant age of 8 WAP. OPEFB compost treatment showed a difference to the control (without compost) but not diference with rice straw compost at 8 WAP (Table 4).

\section{Tabel 4. Effect of organic and inorganic fertilizer on plant height}

\begin{tabular}{|c|c|c|c|c|}
\hline \multicolumn{5}{|c|}{ Plant height $(\mathrm{cm})$} \\
\hline Treatments & & 4 & 6 & 8 \\
\hline & 2 WAP & WAP & WAP & WAP \\
\hline \multicolumn{5}{|l|}{ Organic Fertilizer } \\
\hline $\begin{array}{l}\mathrm{O}_{0}=\text { without compost } \\
\text { application }\end{array}$ & 27.17 & 46.32 & 79.58 & $\begin{array}{l}109.29 \\
\mathrm{a}\end{array}$ \\
\hline $\mathrm{O}_{1}=$ rice straw compost & 29.46 & 46.75 & 90.25 & $\begin{array}{l}124.33 \\
b\end{array}$ \\
\hline $\mathrm{O}_{2}=$ bagasse compost & 28.17 & 52.22 & 80.87 & $\begin{array}{l}112.08 \\
\mathrm{a}\end{array}$ \\
\hline $\mathrm{o}_{3}=\mathrm{OPEFB}$ compost & 28.30 & 55.24 & 92.58 & $\begin{array}{l}121.63 \\
b\end{array}$ \\
\hline \multicolumn{5}{|l|}{ Inorganic Fertilizer } \\
\hline $\begin{array}{l}a_{0}=\text { Without Inorganic } \\
\text { Fertilizer application }\end{array}$ & 26.04 & 45.82 & 78.25 & $\begin{array}{l}106.63 \\
\mathrm{a}\end{array}$ \\
\hline $\begin{array}{l}\mathrm{a}_{1}=50 \% \text { recomendation } \\
\text { dose }\end{array}$ & 30.96 & 52.50 & 91.17 & 123.00 \\
\hline $\begin{array}{l}a_{2}=75 \% \text { recomendation } \\
\text { dose }\end{array}$ & 28.67 & 52.00 & 86.13 & $\begin{array}{l}115.58 \\
b\end{array}$ \\
\hline $\begin{array}{l}\mathrm{a}_{3}=100 \% \\
\text { recomendation dose }\end{array}$ & 27.42 & 50.20 & 87.75 & $\begin{array}{l}122.13 \\
\mathrm{~b}\end{array}$ \\
\hline
\end{tabular}

Note: Numbers followed by the same letter are not significantly different at the 5\% Duncan test level.

Application of inorganic fertilizer 50\% recommended dose showed a significant difference to control of plant height at 8 WAP, but not significantly different from $100 \%$ recommended dose. This is presumably due to the availability of sufficient nitrogen under optimal conditions, so the vegetative phase runs normally.

Compost analysis showed that OPEFB had a higher nitrogen content than other organic fertilizer treatments. According to [22] the provision of OPEFB compost increases the cation 
exchange capacity combined with the addition of inorganic fertilizers so that the availability of nutrients is increased and fulfilled.

\section{Cob Weight of Corn Plant}

Cob weight is one of parameters related to the plant uptake by root system the nutrients from the soil and the amount of photosynthate translocation into seeds. Based on the results of statistical analysis showed that there was no interaction between the application of organic fertilizers with inorganic fertilizers on the weight of the cob with and without the husks. The independent effect of organic fertilizer application showed that there was no significant difference between organic fertilizer treatments and the control but has a tendency to increase the yield (Table 5).

The C-organic content of the soil before treatment was $1.67 \%$ classified as low and increase to $1.88 \%$ after application OPEFB compost. The application of OPEFB compost showed a significant difference compared to the control on the weight of the cobs without husks. This is presumed because organic $\mathrm{C}$ has benefits as a buffer nutrients in soil, so that nutrients are not leached in the soil. Based on [23] research (2019) aplication 10 tons ha ${ }^{-1}$ of OPEFB compost on dry land gave the highest yield of hybrid corn production. OPEFB compost and rice straw compost produced higher weight of cob without husk than control. That is due to the nutrition content of the compost material which can increase corn plant yields. [24] state that increasing $\mathrm{C} / \mathrm{N}$ ratio up to 30 in ensilage process of protein source forage such as Chromolaena odorata will improve nutrient content. Acording to organic residues with $\mathrm{C}: \mathrm{N}>30: 1$ will tie up $\mathrm{N}$ whereas organic residues with $\mathrm{C}: \mathrm{N}<25: 1$ release $\mathrm{N}$ because biological processes reduce $\mathrm{C}: \mathrm{N}$ of materials. The amendment of compost has reduced the $\mathrm{pH}$, increased the $\mathrm{EC}$, and enriched soil with organic matter as far as the rate of the amendment is increasing. The quality of the produced compost depends largely on the level of $\mathrm{C} / \mathrm{N}$ startup ratio and also the quality of its constituents within the mixture [25].

Table 5. Effect of organic and inorganic fertilizer on cobs weight with and without husks

\begin{tabular}{|c|c|c|}
\hline Treatments & $\begin{array}{l}\text { Cobs weight } \\
\text { with husks } \\
\text { (g/plant) }\end{array}$ & $\begin{array}{l}\text { Cobs weight } \\
\text { without husks } \\
\text { (g/plant) }\end{array}$ \\
\hline \multicolumn{3}{|l|}{ Organic Fertilizer } \\
\hline $\mathrm{o}_{0}=$ without compost application & $102.73 \mathrm{a}$ & $83.88 \mathrm{a}$ \\
\hline $\mathrm{O}_{1}=$ rice straw compost & $130.83 \mathrm{a}$ & $112.00 \mathrm{~b}$ \\
\hline $\mathrm{O}_{2}=$ bagasse compost & $117.95 \mathrm{a}$ & $94.97 \mathrm{ab}$ \\
\hline $\mathrm{O}_{3}=\mathrm{OPEFB}$ compost & $132.29 \mathrm{a}$ & $113.86 \mathrm{~b}$ \\
\hline \multicolumn{3}{|l|}{ Inorganic Fertilizer } \\
\hline $\mathrm{a}_{0}=$ Without Inorganic Fertilizer application & $112.92 \mathrm{ab}$ & $93.84 \mathrm{ab}$ \\
\hline $\mathrm{a}_{1}=50 \%$ recomendation dose & $130.78 \mathrm{ab}$ & $109.47 \mathrm{ab}$ \\
\hline $\mathrm{a}_{2}=75 \%$ recomendation dose & $101.00 \mathrm{a}$ & $86.47 \mathrm{a}$ \\
\hline$a_{3}=100 \%$ recomendation dose & $139.12 \mathrm{~b}$ & $114.63 \mathrm{~b}$ \\
\hline
\end{tabular}

Note: Numbers followed by the same letter are not significantly different at the $5 \%$ Duncan test level. 
Vol. 07, No. 01; 2022

ISSN: $2456-8643$

The effect of inorganic fertilizer application showed a significant difference between treatments on cob weight. The application of $100 \%$ inorganic fertilizer recommended dose was significantly different and was a better treatment when compared to treatment with $75 \%$ recommended dose on cob weight with or without husk, but $50 \%$ inorganic fertilizer did not show significant difference to treatment $100 \%$ recommended dose of inorganic fertilizer. Inorganic fertilizers have a higher nitrogen availability than organic fertilizers. According to [26] the availability of nutrients increases the rate of photosynthesis and increases assimilation in seeds so that can increase the weight of the cobs.

\section{CONCLUSION}

The interaction between types of organic fertilizers and doses of inorganic fertilizers did not occur in C-organic, plant nitrogen, chlorophyll, growth and yield of corn plant in Inceptisols Jatinangor. Aplication 10 tons ha ${ }^{-1}$ OPEFB compost was effected to plant nitrogen content was $2.20 \%$, plant height 8 weeks after planting was $121.63 \mathrm{~cm}$ and cob weight without husk was $113.86 \mathrm{~g} /$ plant. The application of $100 \%$ inorganic fertilizer was not difference with $50 \%$ inonganic fertilizer that produced $2.15 \%$ plant nitrogen, chlorophyll $24.88 \mathrm{CCI}$, plant height 8 weeks after planting was $123.00 \mathrm{~cm}$, weight of cob with and without husk were $130.78 \mathrm{~g} / \mathrm{plant}$ and $109.47 \mathrm{~g} /$ plant.

\section{ACKNOLEDGMENT}

The authors acknowledge Universitas Padjadjaran which has funded this research on the implementation of the Research Competency (RKDU) Program 2020.

\section{REFERENCES}

[1]. Sulaiman. A.A., I.K. Kariyasa, Hoerudin. K. Subagyono Suwandi, A. Farid, dan Bahar. 2017. Cara Cepat Swasembada Jagung. Kementrian Pertanian. Indonesia.

[2]. BPS. Badan Pusat Statistik. 2019. Produktivitas Jagung Pulau Jawa dan Luar Jawa 19802019. Jakarta: Badan Pusat Statistik.

[3]. Roba, T.B. 2018. Review on: The Effect of Mixing Organic and Inorganic Fertilizer on Productivity and Soil Fertility. Open Access Library Journal, 5: e4618.

[4]. Schoebitz, M., and Vidal G. 2016. Microbial consortium and pig slurry to improve chemical properties of degraded soil and nutrient plant uptake. Journal Soil Science Plant Nutrition 16(1):226-236.

[5]. Rahman, M.A.A, M.N. El-din, B.M. Refaat, E.H. Abdel-shakour, E.E. Ewais, and H.M.A. Alrefaey. 2016. Biotechnological application of thermotolerant cellulose-decomposing bacteria in composting of rice straw. Journal Annals of Agricultural Science 61(1):135-143.

[6]. Sia, Z. Y., Chng, H. Y. dan Liew, J. Y. 2019. Amending inorganic fertilizers with rice straw compost to improve soil nutrients availability, nutrients uptake, and dry matter production of corn (Zea mays L.) cultivated on a tropical acid soil. AIMS Agriculture and Food, 4(4): 1020-1033.

[7]. Asmarhansyah. 2016. Improving Soil Properties and Yield of Corn (Zea mays L.) by Application of Organic Amendment on Abandoned Tin-Mining Land in Bangka Island. J. Trop Soils, Vol. 21, No. 3, 2016: 141-151. ISSN 0852-257X 
[8]. Dotaniya, M.L., Datta, S.C., Biswas, D.R., Dotaniya, C.K., Meena, B.L., Rajendiran, S., Regar, K.L., Lata, M. 2016. Use of sugarcane industrial by-products for improving sugarcane productivity and soil health. Int. J. Recycl. Org. Waste Agric. 5, 185-194.

[9]. Raza, Q.-U.-A., Bashir, M.A., Rehim, A., Sial, M.U., Ali Raza, H.M., Atif, H.M., Brito, A.F., Geng, Y. 2021. Sugarcane Industrial Byproducts as Challenges to Environmental Safety and Their Remedies: A Review. Water. MDPI. 13, 3495. https://doi.org/ 10.3390/w13243495.

[10]. Azhari. R., Soverda. N. dan Alia. Y. 2018. Pengaruh Pupuk Kompos Ampas Tebu Terhadap Pertumbuhan Dan Hasil Kacang Hijau (Vigna radiata L.). Jurnal Agroecotania 1(2):50-57.

[11]. Sunarwan, B., dan R. Juhana. 2013. Pemanfaatan limbah sawit untuk bahan bakar energi baru dan terbarukan (EBT). Jurnal Tekno Insentif Kopwil 7(2):1-14.

[12]. Syukri. A., Nelvia dan Adiwirman. 2019. Aplikasi kompos tandan kosong kelapa sawit dan pupuk NPKMg terhadap sifat kimia tanah Ultisol dan kadar hara daun kelapa sawit (Elaeis guineensis Jacq). J. Solum Vol. XVI (2):49-59.

[13]. Kurniawan, E., Murniati dan Armaini. 2016. The effect of formulations compos bunches empty oil palm with fertilizer NPK on the growth and production of sweet corn (Zea mays. L Var Saccarata Sturt). Jom Faperta 3(1).

[14]. Bachtiar, T., Waluyo, S.H. dan Syaukat, S.H. 2013. Pengaruh Pupuk Kandang dan SP-36 Terhadap Pertumbuhan Tanaman Padi Sawah Effect of Manure and SP-36 on Growth of Low Land Rice Plants. Journal for The Applications of Isotopes and Radiation Vol. 9 No. 2 Desember 2013, $151-159$.

[15]. Elisabeth, D.W., M. Santosa, N. Herlina. 2013. Pengaruh pemberian berbagai komposisi bahan organik pada pertumbuhan dan hasil tanaman bawang merah (Allium ascalonicum L.). Jurnal Produksi Tanaman 1(3):2338-3976.

[16]. Setyorini D., R. Saraswati, E.A. Anwar. 2006. Kompos. Pupuk Organik dan Pupuk Hayati. Editor: RDM Simanungkalit, Didi Ardi Suridikarta., Rasti Saraswati, Diah Setyorini dan Wiwik Hartatik. Balai Besar Litbang Sumberdaya Lahan Pertanian Badan Penelitian dan Pengembangan Pertanian. 11-40.

[17]. Hartatik, W., Husnain dan W.R. Ladiyani. 2015. Peranan pupuk organik dalam peningkatan produktivitas tanah dan tanaman. Jurnal Sumberdaya Lahan 9(2):107-120.

[18]. Mahmud, K., Panday, D., Mergoum, A., Missaoui, A. 2021. Nitrogen Losses and Potential Mitigation Strategies for a Sustainable Agroecosystem. Sustainability. 13, 2400. https://doi.org/ 10.3390/su13042400.

[19]. Blanco-Canqui H., C.A. Shapiro, C.S. Wortmann, R.A. Drijber, M. Mamo, T.M. Shaver, R.B. Ferguson. 2013. Soil organic carbon: the value to soil properties. J. Soil Water Conservation 68(5):129AA-134A.

[20]. Hutapea, M.N.F., M. Baskara, dan T. Sumarni. 2020. Pengaruh kompos tandan kosong kelapa sawit dan pupuk anorganik pada pertumbuhan dan hasil tanaman jagung pulut (Zea mays ceratina). Jurnal Produksi Tanaman 8(1): 58-65.

[21]. Haryawan, B., J. Sofjan dan H. Yetti. 2015. Pemberian kompos tandan kosong kelapa sawit dan pupuk N, P, K terhadap pertumbuhan dan produksi tanaman jagung manis (Zea mays. L Var saccarata Sturt). Jurnal Online Mahasiswa Faperta. 2(2):110-116. 
Vol. 07, No. 01;2022

ISSN: $2456-8643$

[22]. Haloho, J., Murniati dan S. Yoseva. 2017. Pengaruh permberian kompos TKKS dan pupuk NPK terhadap pertumbuhan dan produksi tanaman jagung (Zea mays L.). Jurnal Online Mahasiswa Faperta 4(1):1-14.

[23]. Moelyohadi, Y. 2018. Respon pertumbuhan dan produksi beberapa varietas jagung hibrida (Zea mays L.) terhadap pemberian jenis kompos limbah perkebunan kelapa sawit pada tingkat pemupukan kimia dosis rendah di lahan kering suboptimal. Jurnal Klorofil 13(2): 104-113.

[24]. Mullik, M.L. G. Oematan, T. Dami Datto, B. Permana, Yelly M. Mulik. 2017. Effects of Carbon:Nitrogen Ratio on Quality of Chromolaena odorata Silage The 7th International Seminar on Tropical Animal Production Contribution of Livestock Production on Food Sovereignty in Tropical Countries September 12-14, Yogyakarta, Indonesia.

[25]. Azim K., Ouyahia K., Amellouk A, Perissol, C., Thami Alami I, Soudi, B. Rahmann G \& Aksoy U (Eds.) 2014. Dynamic composting optimization through C/N ratio variation as a start-up parameter Proceedings of the 4th ISOFAR Scientific Conference. 'Building Organic Bridges', at the Organic World Congress 2014, 13-15 Oct., Istanbul, Turkey (eprint ID 23554)

[26]. Puspadewi S., W. Sutari, Kusumiyati. 2016. Pengaruh konsentrasi pupuk organik cair (POC) dan dosis pupuk N, P, K terhadap pertumbuhan dan hasil tanaman jagung manis (Zea mays L. Var Rugosa Bonaf) kultivar talenta. Jurnal Kultivasi 15(3): 208-216. 